\title{
Samarská kolektivní monografie o současném ruském i zahraničním dramatu
}

ЖУРЧЕВА, Т. В. (ред.): Новейшая драма рубежа ХХ-ХХІ веков: предварительные uтоги. Самара: Самарский университет, 2016. 295 str. ISBN 978-5-7883-1119-7.

Kolektivní monografie Новейшая драма рубежа XX-XXI веков: предварительные umozu vznikla v souvislosti s divadelním seminářem, který se konal nejdříve v ruském Toljatti a posléze v Samaře. Účastníci semináře, jenž byl uveden pod názvem Hoвeǔuaя драма рубежа $X X-X X I$ веков, v průběhu několika let zkoumali tendence převládající v současném ruském i zahraničním dramatu. Publikace je psána v ruštině a do sborníku přispělo devatenáct autorů. Škála témat je široká, od politického charakteru her přes groteskně-fantastické prvky nové dramatiky po studie věnované tvorbě nejvýznamnějších představitelů tohoto hnutí.

Pro čtenáře této publikace je důležité připomenout, že pojem новая драма (čes. nové drama) byl už dříve používán v souvislosti s dramatem z konce 19. a 20. století. Proto někteří badatelé označují drama přelomu 20. a 21. století pojmem новейшая драма (čes. nejnovějši drama), jak je ostatně uvedeno v samotném názvu sborníku.

V první kapitole „Новая драма“: история и география definuje M. I. Sizovová „nové drama“ jako protestní hnutí mladé generace. Autorka zmiňuje dvě vlny, první se vztahuje k devadesátým letům a začátek druhé je datován rokem 1998. Představitelé první vlny stáli před otázkou, kde a jak inscenovat nové hry. Ukázalo se totiž, že tzv. repertoárová divadla nejsou ochotna na své scéně uvádět nové netradiční hry. Mnohá díla první vlny tedy čekala na své uvedení až do roku 1998, kdy bylo v Moskvě založeno divadlo Центр драматургии и режиссуры, které se záhy stalo otevřenou scénou pro většinu mladých dramatiků i režisérů.

V příspěvku Действие в новейшей драме рубежа XX-XXI веков se L. G. Ťutělovová soustředí na narušení tradičního, aristotelovského pojetí děje v dramatu. Autorka sleduje zvláštnosti a proměny děje v současném dramatu - zejména zdo̊razňuje, jak se ztrácí objektivnost zobrazovaného a vzniká „jiná skutečnost“, prostor, kde dochází ke komunikaci hrdiny a postranního pozorovatele, tedy čtenáře či diváka.

Již název studie O.V.Žurčevové Трагическое и трагедия в новейшей драме odkazuje k předmětu výzkumu. Autorku zajímá vztah tragédie a tragického - tragédie jako žánr se podle ní ve 2o. století dostává do pozadí, zatímco tragické v reálném životě nabývá na síle.

S. M. Bolgovová se ve své stati Документальная драма сегодня: типология стилевых и жанровых форм věnuje dokumentárnímu rázu současných her. Vyzdvihuje 
především techniku verbatim, která je založena na doslovné rekonstrukci nahraného materiálu. $\mathrm{S}$ její pomocí se dramatici vyjadřují $\mathrm{k}$ velmi komplikovaným tématům, jako jsou teroristické útoky na beslanskou školu či v moskevském divadle Dubrovka nebo nedávné události na Ukrajině. K nejvýraznějším scénám pracujícím s technikou verbatim patří divadlo Teaтp.doc.

Stat' T. V. Boldyrevové Политизация художественного сознания в современном театрально-драматургическом пространстве je věnována stále významnější roli umění $\mathrm{v}$ politicko-společenském procesu. Divák nemůže přehlédnout silně protestní sdělení většiny her (uvedených zejména na prknech výše zmíněného divadla Театр.doc), divadelní scéna totiž v mnohém nahradila neexistující prostor pro svobodnou diskusi. Výrazně se projevuje žánr antiutopie. Dramatici tak prostřednictvím obrazů z blízké, často totalitní budoucnosti odkazují k problémům současnosti. Což vede, přemýšlí Boldyrevová, $\mathrm{k}$ úvahám o tom, co znepokojujícího se vlastně kolem nás děje.

L.S. Kislovová si všímá feministické roviny nové dramatiky. Její studie „Время амазонок": феминистская драматургия рубежа XX-XXI веков ukazuje, с̌́́m se feministické téma $\mathrm{v}$ dramatech $\mathrm{z}$ přelomu 20. a 21. století liší od těch dřivějších.

S.P. Lavlinskij a A.M.Pavlov přispěli do sborníku jako spoluautoři dvou studií. V první z nich s názvem Гротескно-фантастические аспекты новейшей драматургиu se věnují křehké hranici mezi „možným“ a „nemožným“. Skutečnost, že současní dramatici stavějí mnohé své hry na absenci této hranice, autoři připisují krizi identity, pocitu ztracení a váhavosti, jimž čelí moderní člověk. Ve svém dalším článku O перформативно-рецептивном потенциале современной драматургии se soustředí na roli diváka/čtenáře $\mathrm{v}$ procesu inscenace hry.

Další autorská dvojice, $\mathbf{O}$. V. Semenickaja a A. V. Sinickaja, se představuje statí Ре-визия „слепого пятна“: проблема визуальности в новейшей драме. Autorky analyzují vizuální prostředky současného dramatu, jehož součástí se staly různé filmové projekce, reklamní spoty či ukázky z televizní produkce.

Mezi zmiňovanými dramatiky vévodí jméno Nikolaje Koljady, jehož tvorbě je věnována práce J. A. Starovové Николай Коляда - солнце русской драматургии. Nikolaj Koljada patří bezpochyby k nejčastěji inscenovaným současným ruským dramatikům nejen na domácí scéně, ale i v zahraničí.

Práce V.B.Šaminové Театр шоковой терапии se soustředí na fenomén tzv. in-yer-face-theatre, tedy otevřeně agresivního a provokativního divadla - to se objevuje na začátku 9o. let $\mathrm{v}$ Británii.

Dílem Marka Ravenhilla, předního představitele současného britského dramatu, se zabývá př́spěvek J. G. Docenkové Драматургия Марка Равенхилла: этапы, темы, мотивы, образы. Autorka sleduje téměř dvacet let dramatikovy práce, od inscenace jeho slavné hry Shopping and Fucking (1996) až po jeho poslední práce z roku 2015. 
J. N. Ševčenková přispěla studií s názvem Новая немецкая драма: новаторство и традиция. Na několika konkrétních příkladech ukazuje, jakým způsobem mladí dramatici překonávají postdramatický přistup $\mathrm{k}$ divadlu a přiklánějí se ke realistickému divadlu, čímž se vracejí k tradicím, reprezentovaným např́klad tvorbou B. Brechta.

Práce „Пьеса по пьесе“ в творчестве Х. Мюллера и П. Хакса N.E. Sejbelové se soustředí na tvorbu dvou výrazných německých dramatiků druhé poloviny 20. století, Heinera Müllera a Petera Hackse. Oba vycházejí z klasických her, originál však obohacují o mnohé prvky ze své současnosti a díky tomu vytvářejí obrazy stále se opakující historické situace.

J.M. Lepiševová srovnává ve své studii Модификация конфликта в русской и белорусской драматургии конца XX - начала XXI веков ruské a běloruské drama posledních desetiletí. Autorka analyzuje konflikt v několika vybraných hrách a nachází společné prvky, a to především zobrazení reálií postsovětské společnosti na základě sociálně-existenciální kolize.

Hry ukrajinsko-ruského dramatika Alexandra Mardaně zkoumá N. P. Maljutinová v př́spěvku Процессы приращивания смысла и контекстная интерпретащия пьес А. Марданя. Při analýze jeho stěžejních děl vyzdvihuje především dramatikovu práci s jazykem a stereotypy masové kultury.

Studie L. P. Šatinové Драматический текст в новом „драматическом дискурсе“: „Ручейник“В. Дурненкова и „Ручейник, или Куда делся Андрей?“С. Александровского se zabývá novými postupy $\mathrm{v}$ současném dramatu. Autorka mluví především o postdramatickém divadle, $\mathrm{v}$ němž klasický konflikt ztrácí funkci a zůstává $\mathrm{v}$ pozadí. Každý umělecký znak nese svůj vlastní kód a jejich kombinování znesnadňuje pochopení divadelního jazyka. Současně však, jak podotýká Šatinová, tento složitý jazyk odráží složité uspořádání světa.

Zvláštní pozornost si jistě zaslouží poslední př́íspěvek sborníku, „Тольяттинская драматургия“ “как провинциальный литературный проект. Jeho autorka T. V.Žurčevová zkoumá tzv. toljattinský mýtus. Průmyslové město Toljatti se svou zvláštní historií - původní město Stavropol na Volze, které se nacházelo na místě budoucí Kujbyševské přehrady, bylo v roce 1955 přemístěno a posléze přejmenováno na počest italského komunisty Palmira Togliattiho - se stává dějištěm nejedné hry představitelů nového dramatu. Jak Žurčevová zdůrazňuje, město je reprezentováno konkrétními názvy a místními reáliemi, současně si ale zachovává svůj mytický ráz prostoru bez minulosti.

V názvu sborníku čteme предварительные итоги (čes. předběžné závěry). Cílem tedy není představit jasné, konkrétní závěry. Nové drama se stále vyvijí, je to živý proces a jeho směr nelze předpovědět. Tato skutečnost vysvětluje určitou nevyváženost celé publikace, a to především mluvíme-li o různorodosti témat jednotlivých studií a pozornosti věnované ruským a zahraničním dramatikům. 
Navzdory své neuzavřenosti však přináší přehled nejvýraznějších osobností, her i divadelních souborů. Proto může daná monografie sloužit jako velmi užitečný materiál pro ruské filology i divadelní teoretiky. A také pro všechny, kteří se zajímají o proměny současného divadla a umění obecně.

Př́nosem sborníku je především snaha většiny autorů představit nové drama jako medium, které - ač nahlíženo z různých úhlů pohledu - je důležitou součástí dialogu ve společnosti. Autory spojuje často zmiňovaná krize (rus. кризис самоидентификации, кризисное состояние, духовный кризис, кризис слова...) jakožto základní impuls tvorby současných dramatiků. Můžeme jen hádat, nakolik je to přirozená vlastnost umění jako takového - vždy vybírat polemická, provokativní a bolestivá témata - či nakolik je to spojeno s kritickým stavem společnosti na přelomu dvou století.

Anna Danielová

\section{Literatura:}

ŽURČEVA, T. V. (red.): Novejšaja drama rubeža XX-XXI vekov: predvaritel'nyje itogi. Samara: Samarskij universitet, 2016.

https://doi.org/10.5817/OS2019-1-12

\section{Книга о метапоэтике Збигнева Херберта}

BOBRYK, R.: Koncept poezji i poety $w$ wierszach Zbigniewa Herberta. Siedlce, 2017. 229 str.

Русский читатель знаком с творчеством Збигнева Херберта, одного из наиболее значительных польских поэтов XX в., по нескольким уже переведенным его книгам (включая эссеистику), по ряду подборок, опубликованных в периодике, отдельных антологиях и в Интернете. В Польше его имя пользуется широким признанием, свидетельство чему - недавно вышедшая книга Романа Бобрыка.

В хербертовском творчестве пристальное внимание к многообразным реалиям мира сочетаются с основательным интеллектуализмом и метафизической рефлексией (в том числе в виде саморефлексии). Неизменный момент самоанализа поэта, его интереса к своему авторскому становлению - 